\title{
Protective role of Stokeyia indica in liver dysfunction and associated complications in acetaminophen intoxicated rats
}

\author{
Darakhshan Taj ${ }^{1}$, Amna Tariq ${ }^{2}$, Viqar Sultana ${ }^{1 *}$, Jehan Ara², Viqar Uddin Ahmad ${ }^{3}$ and Syed Ehteshamul-Haque ${ }^{4}$
}

\begin{abstract}
Background: Acetaminophen is an efficient painkiller usually safe when used in therapeutic doses. It may cause hepatotoxicity when overdosed and triggers nephrotoxicity as well, besides affecting lipid and glucose metabolism. Marine macro-algae possesses various biological activities including hepatoprotective. Stokeyia indica is a brown alga, found abundantly at Karachi coast is known to possess antioxidant and hypoglycemic activities. In this study, we evaluated its hepatoprotective role against damage induced by acetaminophen and associated complications like kidney dysfunction.

Method: To evaluate hepatoprotective role of S.indica against damage induced by acetaminophen and associated complications, male Wistar rats were used. Rats were separated into four groups; each group consists of six rats. Group I was control, group II was acetaminophen dosed group. While group III rats were pretreated with seaweed and then given acetaminophen and group IV rats were given seaweed only. Rats from group III and IV were pretreated daily for 14 days orally with ethanol extract of seaweed $(200 \mathrm{mg} / \mathrm{kg})$. Group I and II were orally administered distilled water daily for 14 days. Group II and III were intraperitoneally injected with acetaminophen (1 g/Kg) on day 14 th. Liver enzymes (Alanine transaminase (ALT), Alkaline phosphatase (ALP), Aspartate transaminase (ASAT), Lactate dehydrogenase $(\mathrm{LDH})$ and other biochemical parameter including (glucose, urea, creatinine, cholesterol, triglycerides, bilirubin-total \& bilirubin-direct) were estimated. Lipid peroxidation in liver was estimated by the formation of malondialdehyde (MDA). Histopathological analyses was also carried out. Two oily fractions eluted from the ethanol extract of S. indica through column chromatography were characterized by using GC-MS.

Result: The ethanol extract of $S$. indica was found to attenuate the adverse effect of acetaminophen on liver function and disorders of kidney and glucose metabolism in acetaminophen dosed rats. Evident from the lowering of the elevated level of bilirubin, urea and creatinine and blood glucose towards normal range, besides normalizing the cardiac and liver enzymes. These biochemical estimations were also confirmed by a histopathological study of liver. In column chromatography ethanol extract of S.indica yielded oily fractions, showed presence of various fatty acids when subjected to GC-MS analysis.

Conclusion: Our study showed the hepatoprotective role of ethanol extract of S. indica. It can be concluded that seaweed S.indica had therapeutic and preventive effect against acetaminophen induced hepatic oxidative stress may be due to the presence of methyl palmitate.
\end{abstract}

Keywords: Acetaminophen, Toxicity, Stokeyia indica, Liver function, Kidney, Histopathology

\footnotetext{
* Correspondence: viqarsultana98@hotmail.com

${ }^{1}$ Department of Biochemistry, University of Karachi, Karachi 75270, Pakistan

Full list of author information is available at the end of the article
} 


\section{Background}

Certain medicinal agents can cause injury to the different organs, either used as directed or when taken in high doses [1]. Hepatotoxicity may induce by herbal products, chemical agents (chemicals used in industries and laboratories) and natural chemicals like microcystins. More than 900 drugs have been linked to cause liver injury and it is the most common reason for a drug to be withdrawn from the market $[2,3]$.

Acetaminophen is a widely used analgesic-antipyretic drug known to cause hepatotoxicity when overdosed [4]. Conversely, an unintentional or purposely overdose frequently causes acute liver failure [5]. Once the liver became injured, its efficient treatment with drug like glycyrrhizin is limited [6]. Consequently, interest in the utilization of alternative medicines for the treatment of hepatic disease has been increased $[7,8]$. Seaweeds are also prosperous in bioactive compounds with antiviral, antioxidant, anti-inflammatory, antimicrobial and antitumor activities [9-11]. Marine macro-algae (seaweeds), despite their abundance, are poorly exploited, even though their total lipid content is usually low [12], but contain a high amount of polyunsaturated fatty acids (PUFA). The fatty acids have various biological activities [13-15].

Stokeyia indica is a brown alga, found abundantly at Karachi coast [16], possess various biological activities including cytotoxic [17, 18], hypolipidemic [19] and hypoglycemic [20]. In our previous studies, ethanol extract and polysaccharides fractions of $S$. indica showed strong antioxidant activity $[10,11]$. In the present study we have evaluated its hepatoprotective role against damaged induced by acetaminophen and associated complications. Two oily fractions eluted from the ethanol extract of $S$. indica through column chromatography were characterized by using GC-MS.

\section{Methods}

\section{Chemicals}

Kits for the estimation of biochemical parameter including glucose, cholesterol, triglycerides, urea, creatinine, totalbilirubin, direct-bilirubin and liver enzymes (ALP, ASAT, LDH \& ALAT) were purchased from Merck Limited, France, and Ecoline, Germany. Acetaminophen was purchased from Sigma Aldrich, U.S.A. In this study, other reagents were used also of analytical status.

\section{Seaweed collection and preparation of ethanol extract}

The seaweed, Stokeyia indica was collected from Buleji beach of Karachi coast at low tide and was identified. This seaweed was rinsed with water thoroughly in order to remove soil particles and adhered debris. For experimental use seaweed was dried, drudged in fine powder and stored. Stokeyia indica dried powder (500 g) was soaked in $2 \mathrm{l}$ of distilled ethanol at room temperature for 1 week. The filtrate was collected and concentrated on a Buchi R-200 rotary vacuum evaporator at $40{ }^{\circ} \mathrm{C}$. A final concentrated form of the extract was stored in a brown bottle at room temperature.

\section{Experimental design}

Male Wistar rats (140-180 g) were acquisitioned from Dow University of Health Sciences, Karachi, Pakistan. Rats were fed with a regular laboratory diet and tap water in animal house. They were separated into four groups, all group consists of six rats. Group I and II rats were orally administered distilled water daily for 14 days. Group III and IV rats pretreated daily for 14 days orally with $S$. indica ethanol extract $(200 \mathrm{mg} / \mathrm{kg})$. Group II and III rats were intraperitoneally injected with acetaminophen $(1 \mathrm{~g} / \mathrm{kg}$ ) dissolved in $40 \%$ PEG 400 (Polyethylene Glycol 400 ) in $0.9 \% \mathrm{NaCl}$ solution on day 14 th. Before decapitation rats were fasted for $12 \mathrm{~h}$. On day 15 th rats were weighed and decapitated by cervical dislocation. Blood samples were collected and Serums were alienated after centrifugation for $10 \mathrm{~min}$ at $3000 \mathrm{rpm}$ and stored at $-20{ }^{\circ} \mathrm{C}$ until used. Liver and kidney were rapidly dismembered, rinsed with ice-cold normal saline $(0.9 \%)$, blotted dry, weighed and saved at $-20^{\circ} \mathrm{C}$ for analysis.

\section{Assessment of biochemical parameters}

Hepatotoxicity was evaluated by the serum liver enzyme profile (alanine aminotransferases [ALAT), aspartate aminotransferases [ASAT), alkaline phosphatase [ALP), lactate dehydrogenase [LDH) and bilirubin (total and direct). Nephrotoxicity was evaluated by estimating serum kidney enzyme profile (urea, creatinine) and other parameters (glucose, cholesterol, triglycerides) were also estimated. All tests were performed using blood chemistry analyzer (Microlab-300, Merck, France); kits were purchased from Merck (France) and Ecoline (Germany).

\section{Estimation of lipid peroxides and hepatic glutathione}

Lipid peroxidation in liver was estimated by the formation of malondialdehyde (MDA). 10\% homogenate was prepared by homogenizing liver tissues through $0.15 \mathrm{M}$ Tris - $\mathrm{HCl}$ (PH 7.4) with Poly Tron (Kinematic) PT-MR 2100 homogenizer. The homogenates were used for the measurement of thiobarbituric acid reactive substance (TBARS) to evaluate lipid peroxidation [21] and also used for reduced glutathione [22].

\section{Histopathological analysis}

For histopathological analyses liver samples were preserved in 5\% phosphate-buffered neutral formalin, dehydrated in graded (30-100\%) ethanol and fixed in paraffin. Sections were cut down at $3-\mu \mathrm{m}$ thickness and stained with hematoxylin and eosin stain and then observed under 
Table 1 Absolute weights (g) and relative weights (\%) of liver and kidney tissues in different groups of rats

\begin{tabular}{llllll}
\hline Groups & Dose $(\mathrm{mg} / \mathrm{kg})$ & $\begin{array}{l}\text { Absolute liver } \\
\text { weight }(\mathrm{g})\end{array}$ & $\begin{array}{l}\text { Relative liver } \\
\text { weight (\%) }\end{array}$ & $\begin{array}{l}\text { Absolute Kidney } \\
\text { weight (g) }\end{array}$ & $\begin{array}{l}\text { Relative Kidney } \\
\text { weight }(\%)\end{array}$ \\
\hline Control & - & $2.24 \pm 0.18^{\mathrm{c}}$ & $1.27 \pm 0.105^{\mathrm{c}}$ & $0.43 \pm 0.017^{\mathrm{c}}$ & $0.24 \pm 0.006^{\mathrm{c}}$ \\
Acetaminophen treated rats & $1 \mathrm{~g} / \mathrm{kg}$ & $3.74 \pm 0.15^{\mathrm{a}}$ & $1.97 \pm 0.08^{\mathrm{a}}$ & $0.71 \pm 0.01^{\mathrm{a}}$ & $0.38 \pm 0.006^{\mathrm{a}}$ \\
Stokeyia indica pre-treated + Acetaminophen & $200 \mathrm{mg} / \mathrm{kg}+1 \mathrm{~g} / \mathrm{kg}$ & $2.86^{*} \pm 0.22^{\mathrm{b}}$ & $1.68^{*} \pm 0.13^{\mathrm{b}}$ & $0.59^{*} \pm 0.05^{\mathrm{b}}$ & $0.34^{*} \pm 0.025^{\mathrm{b}}$ \\
\hline
\end{tabular}

The values are expressed as means \pm Standard Deviation ( $n=6$ animals per group)

Means values in column bearing same superscript letter are not significantly $(p<0.05)$ different according to Duncan's Multiple Range Test

*Significant at $p<0.05$ as compared to acetaminophen control

a light microscope at 40x magnification to studied histopathological alteration in liver structural design, and were taken photomicrographs of all samples.

\section{Column chromatography and GC-MS analysis}

Ethanol extract of Stokeyia indica was loaded on prepacked silica gel column (Column filled through silica gel, G 60 in n-hexane). Two fractions (F46 and F47) eluted from $15 \%$ methanol in chloroform $(15: 85)$ were oily in nature. They were analyzed on Gas Chromatograph (Agilent Model $6890 \mathrm{~N}$ ) in combination with a Mass Spectrometer (JMS-600 H Jeol). GC temperature planned as of $70{ }^{\circ} \mathrm{C}$ to $260{ }^{\circ} \mathrm{C}$ with a rate of $5{ }^{\circ} \mathrm{C} / \mathrm{min}$. The injection port temperature held at $\left(260{ }^{\circ} \mathrm{C}\right)$ and the mover gas $\mathrm{He}$ (helium) was run at the speed of $(1 \mathrm{ml} / \mathrm{min})$.

\section{Statistical analysis}

Statistical analysis for comparing the data was performed by using IBM SPSS Statistics software, version 20 (IBM Corp., Pakistan). Results are showed as mean \pm SD by using the analysis of variance (one-way ANOVA) followed by Duncan's multiple range test to find out the differences between the averages at $(P<0.05)$ significance value.

\section{Results}

The absolute and relative weight of the liver and kidney were significantly $(P>0.05)$ elevated by acetaminophen intoxication as compared to normal control group rats. Whereas pretreatment with S.indica ethanol extract before acetaminophen intoxication prevent the negative effect of the toxicant on organ weight (Table 1). Group II rats treated with a single injection of acetaminophen developed hepatic damage as compared to the normal control rats. It was manifest from a distinct increased within the concentration of hepatic and cardiac enzymes (ALAT, ASAT, ALP, and LDH) and other biochemical parameters including bilirubin (total \& direct). Acetaminophen intoxication also affects kidney function, glucose, and lipid metabolism by elevating the level of creatinine and urea, glucose and triglyceride and decreasing the total cholesterol (Table 2). Stokeyia indica pretreated group rats showed a significant $(P<0.05)$ improvement in the level of the altered biochemical parameter as compared to the acetaminophen control rats. Whereas elevated levels of bilirubin, creatinine, urea, glucose, and triglyceride were found decreased towards normal range with increased in total cholesterol. The increased concentration of cardiac and liver enzymes was also found decreased towards normal range in rats pretreated with seaweed as compared to rats intoxicated with acetaminophen only (Table 2). Stokeyia indica control group rats showed the non-toxic effect on liver enzymes and biochemical markers.

Acetaminophen administration increased the concentration of MDA and decreased glutathione concentration. Stokeyia indica pre-treated rats alleviated these changes via decreasing the concentration of MDA and escalating the concentration of reduced glutathione (Table 3).

The histopathological analysis of liver confirmed the observed modification of serum enzymatic levels to liver

Table 2 Effect of Stokeyia indica ethanol extract on serum biochemical parameters in normal and acetaminophen intoxicated rats

\begin{tabular}{|c|c|c|c|c|c|c|c|c|c|c|c|}
\hline Groups & $\operatorname{ALAT}(\mathrm{U} / \mathrm{L})$ & ASAT (U/L) & $\operatorname{ALP}(U / L)$ & $\mathrm{LDH}(\mathrm{U} / \mathrm{L})$ & $\begin{array}{l}\text { Total } \\
\text { bilirubin } \\
(\mathrm{mg} / \mathrm{dl})\end{array}$ & $\begin{array}{l}\text { Direct } \\
\text { bilirubin } \\
(\mathrm{mg} / \mathrm{dl})\end{array}$ & Creatinine $(\mathrm{mg} / \mathrm{dl})$ & Urea (mg/dl) & $\begin{array}{l}\text { Glucose } \\
\text { (mg/dl) }\end{array}$ & $\begin{array}{l}\text { Cholesterol } \\
(\mathrm{mg} / \mathrm{dl})\end{array}$ & $\begin{array}{l}\text { Triglyceride } \\
\text { (mg/dl) }\end{array}$ \\
\hline Control & $24.2 \pm 0.9^{c}$ & $75.5 \pm 2.6^{c}$ & $94.2 \pm 2.5^{b}$ & $256.5 \pm 4.6^{c}$ & $0.45 \pm 0.06^{b}$ & $0.1 \pm 0^{c}$ & $0.82 \pm 0.05^{b}$ & $23.7 \pm 3.3^{c}$ & $91.2 \pm 1.7^{b}$ & $87.2 \pm 0.9^{\mathrm{a}}$ & $97.0 \pm 4.1^{b}$ \\
\hline $\begin{array}{l}\text { Acetaminophen } \\
\text { treated rats } \\
(1 \mathrm{~g} / \mathrm{kg})\end{array}$ & $66.0 \pm 1.8^{\mathrm{a}}$ & $289.5 \pm 2.1^{\mathrm{a}}$ & $142.0 \pm 4.9^{\mathrm{a}}$ & $386.2 \pm 2.6^{\mathrm{a}}$ & $0.8 \pm 0.08^{a}$ & $0.3 \pm 0.01^{\mathrm{a}}$ & $1.25 \pm 0.06^{\mathrm{a}}$ & $48.5 \pm 1.9^{\mathrm{a}}$ & $137 \pm 1.8^{\mathrm{a}}$ & $54.5 \pm 1.3^{d}$ & $121.2 \pm 2.9^{\mathrm{a}}$ \\
\hline $\begin{array}{l}\text { Stokeyia indica } \\
\text { pre-treated + } \\
\text { acetaminophen }\end{array}$ & $33.2^{*} \pm 1.70^{b}$ & $205.2^{*} \pm 4.1^{b}$ & $96.5^{*} \pm 5.9^{b}$ & $290.0^{*} \pm 3.7^{b}$ & $0.50^{*} \pm 0.1^{b}$ & $0.15^{*} \pm 0.06^{b c}$ & $0.85^{*} \pm 0.06^{b}$ & $30.2^{*} \pm 1.2^{b}$ & $80.2^{*} \pm 2.6^{c}$ & $67.5^{*} \pm 2.1^{b}$ & $91.2^{*} \pm 2.7^{c}$ \\
\hline $\begin{array}{l}\text { S. indica } \\
(200 \mathrm{mg} / \mathrm{kg})\end{array}$ & $20.5 \pm 1.0^{d}$ & $66.5 \pm 1.7^{d}$ & $82.0 \pm 3.6^{c}$ & $227.0 \pm 5.0^{d}$ & $0.45 \pm 0.1^{b}$ & $0.2 \pm 0.08^{b}$ & $0.7 \pm 0.08^{c}$ & $28.2 \pm 2.4^{b}$ & $76.2 \pm 3.1^{d}$ & $63.0 \pm 1.4^{c}$ & $70.0 \pm 1.6^{d}$ \\
\hline
\end{tabular}

The values are expressed as means \pm Standard Deviation ( $n=6$ animals per group)

Means values in column bearing same superscript letter are not significantly $(p<0.05)$ different according to Duncan's Multiple Range Test

*Significant at $p<0.05$ as compared to acetaminophen control 
Table 3 Effect of Stokeyia indica on hepatic malondialdehyde (MDA) and glutathione concentration in acetaminophen intoxicated rats

\begin{tabular}{|c|c|c|c|}
\hline Groups & Dose (mg/kg) & MDA ( $\mu$ mole/g liver tissue) & Glutathione ( $\mu$ mole/g liver tissue) \\
\hline Group I (Control) & - & $7.97 \pm 0.04^{c}$ & $16.1 \pm 1.89^{\mathrm{a}}$ \\
\hline Group II (Acetaminophen treated rats) & $1 \mathrm{~g} / \mathrm{kg}$ & $13.3 \pm 0.35^{\mathrm{a}}$ & $7.89 \pm 0.77^{b}$ \\
\hline Group III (S. indica pre-treated+ Acetaminophen) & $200 \mathrm{mg} / \mathrm{kg}+1 \mathrm{~g} / \mathrm{kg}$ & $10.7^{*} \pm 1.43^{\mathrm{b}}$ & $14.4^{*} \pm 5.02^{\mathrm{a}}$ \\
\hline
\end{tabular}

The values are expressed as means \pm Standard Deviation ( $n=6$ animals per group)

Means values in column bearing same superscript letter are not significantly $(p<0.05)$ different according to Duncan's Multiple Range Test

*Significant at $p<0.05$ as compared to acetaminophen control

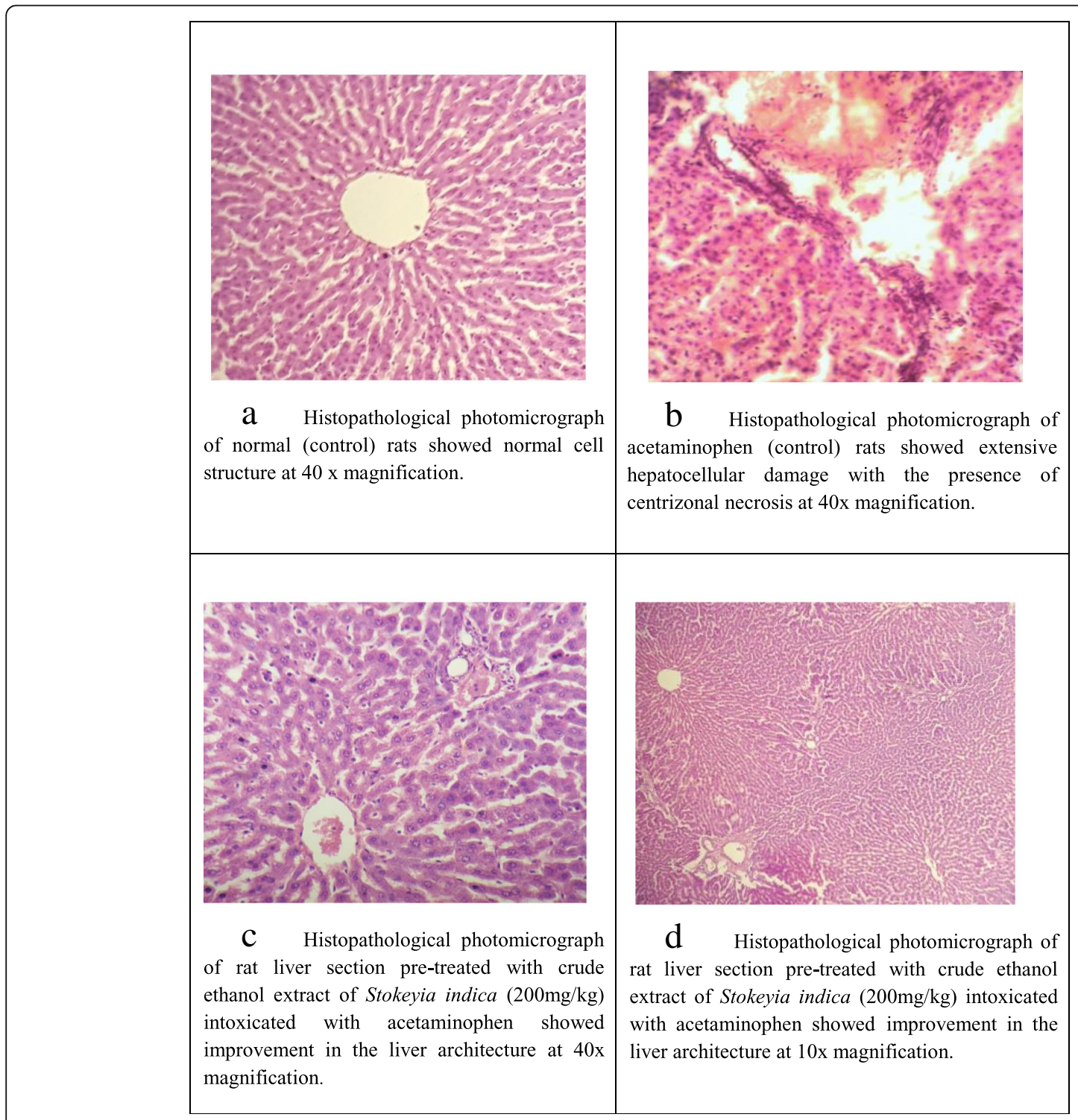

Fig. 1 (a, b, c, d) Histopathology analysis of liver sections in normal, acetaminophen treated and Stokeyia indica (40X,10X) treated rats model. a Histopathological photomicrograph of normal (control) rats showed normal cell structure at $40 \mathrm{x}$ magnification. $\mathbf{b}$ Histopathological photomicrograph of acetaminophen (control) rats showed extensive hepatocellular damage with the presence of centrizonal necrosis at 40x magnification. $\mathbf{c}$ Histopathological photomicrograph of rat liver section pre-treated with crude ethanol extract of Stokeyia indica $(200 \mathrm{mg} / \mathrm{kg})$ intoxicated with acetaminophen showed improvement in the liver architecture at 40x magnification. $\mathbf{d}$ Histopathological photomicrograph of rat liver section pre-treated with crude ethanol extract of Stokeyia indica $(200 \mathrm{mg} / \mathrm{kg})$ intoxicated with acetaminophen showed improvement in the liver architecture at 10x magnification 
injury and their attributes on health. Normal hepatic architecture was observed in the liver sections of control rats with a central vein and hepatocytes radiating from it (central vein) (Fig. 1a), while liver section of acetaminophen treated animals showed centrilobular necrosis with vacuolar cytoplasmic deterioration around the central vein, hepatic degeneration, destruction of lobular architecture and nuclear degeneration in certain areas, (Fig. 1b). These were markedly diminished by administration of $S$. indica ethanol extract $(200 \mathrm{mg} / \mathrm{kg})$ and showed improvement in the liver architecture (Fig. 1c and d).

Fractions F46 and F47 of ethanol extract of Stokeyia indica eluted from column chromatography were analyzed by GC-MS to detect various compounds. The constituents identified in the fraction F46 were identified as Methyl- $n$-Nonadecanoate $\left(\mathrm{C}_{20} \mathrm{H}_{40} \mathrm{O}_{2}\right)$, MethylHexeicosanoate $\left(\mathrm{C}_{22} \mathrm{H}_{44} \mathrm{O}_{2}\right)$ (Table 4).

Fraction $\mathbf{F 4 7}$ revealed the existence of Methyl- $n$-Nonadecanoate $\left(\mathrm{C}_{20} \mathrm{H}_{40} \mathrm{O}_{2}\right)$, Methyl- $n$-Hexadecanoate $\left(\mathrm{C}_{17} \mathrm{H}_{34} \mathrm{O}_{2}\right)$, Methyl Octadecanoate $\left(\mathrm{C}_{19} \mathrm{H}_{38} \mathrm{O}_{2}\right)$, Octadecanoic acid, Butyl ester $\left(\mathrm{C}_{22} \mathrm{H}_{44} \mathrm{O}_{2}\right)$ (Table 5).

\section{Discussion}

Liver diseases are important problem all over the world and it is increasing day after day. The drug induced liver injury (DILI) may leads in increased concentrations of serum enzymes like, ASAT, ALAT, ALP, along with increase in serum bilirubin, glucose, triglycerides, urea and creatinine [4]. In the current study, seaweed, S.indica ethanol extract efficiently attenuates the acetaminopheninduced hepatotoxicity by ameliorating the activities of these serum enzymes and also improved total and direct bilirubin concentration. Compernolle et al. [23] reported that increasing concentration of bilirubin metabolite in blood serum is utilized as an indicator of liver damage. It has been reported that bilirubin concentration increased as a consequence of enlarged production, reduced uptake through the liver, decreased conjugation, decreased discharge from the liver or obstruction of the bile duct $[24,25]$. These results confirmed prior reports that acetaminophen has an unsafe and hectic pressure on liver tissues [26, 27].

In the current study, acetaminophen intoxication also produced an adverse effect on kidney function as manifested in the increased level of creatinine and urea in the blood. Overdose of paracetamol become the reason for many metabolic disorders as well as an increase in serum urea and creatinine [28]. The enhancement in serum urea and creatinine concentrations provides a significant indication of renal toxicity [29]. Seaweed pretreated intoxicated rats showed decreased level of creatinine and urea concentration towards normal range as compared to acetaminophen intoxicated rats, which showed elevated level of kidney parameters.

Lipid metabolism and kidney functions may be affected by liver damage [30]. In this study, rats intoxicated with acetaminophen also showed a disturbance in lipid metabolism, by increasing triglyceride level and decreasing total

Table 4 GC-MS of Fraction F46 from Stokeyia indica

\begin{tabular}{|c|c|c|c|c|c|c|}
\hline Scan No. & Systematic Name & Common Name & Molecular Formula & Mol. Wt. & Retention Time & Mass \& Fragmentation Pattern \\
\hline 328 & Methyl-n-nonadecanoate & & $\mathrm{C}_{20} \mathrm{H}_{40} \mathrm{O}_{2}$ & 312 & 15.53 & $\begin{array}{l}\text { GC-MS m/z: rel. Inten: } 312\left(\mathrm{M}^{+},\right. \\
7 \%), 269\left(\mathrm{M}^{+}-2,43 \%\right), 257 \\
\left(\mathrm{M}^{+}-55,60 \%\right), 239\left(\mathrm{M}^{+}-73,\right. \\
38 \%), 227\left(\mathrm{M}^{+}-85,3 \%\right), 213 \\
\left(\mathrm{M}^{+}-99,9 \%\right), 199\left(\mathrm{M}^{+}-113,\right. \\
2 \%), 185\left(\mathrm{M}^{+}-127,7 \%\right), 171 \\
\left(\mathrm{M}^{+}-141,5 \%\right), 157\left(\mathrm{M}^{+}-155,\right. \\
4 \%), 143\left(\mathrm{M}^{+}-169,3 \%\right), 129 \\
\left(\mathrm{M}^{+}-183,26 \%\right), 116\left(\mathrm{M}^{+}-\right. \\
196,9 \%), 97\left(\mathrm{M}^{+}-215,9 \%\right), 85 \\
\left(\mathrm{M}^{+}-227,10 \%\right), 73\left(\mathrm{M}^{+}-239,\right. \\
24 \%), 56\left(\mathrm{M}^{+}-256,100 \%\right), 41 \\
\left(\mathrm{M}^{+}-271,28 \%\right) .\end{array}$ \\
\hline 409 & $\begin{array}{l}\text { Methyl-hexeicosanoate } \\
\text { (methyl hexeicosanoate) }\end{array}$ & & $\mathrm{C}_{22} \mathrm{H}_{44} \mathrm{O}_{2}$ & 340 & 18.63 & $\begin{array}{l}\text { GC-MS m/z: rel. Inten: } 340\left(\mathrm{M}^{+} \text {, }\right. \\
11 \%), 285\left(\mathrm{M}^{+}-55,66 \%\right), 267 \\
\left(\mathrm{M}^{+}-73,37 \%\right), 241\left(\mathrm{M}^{+}-99,\right. \\
13 \%), 227\left(\mathrm{M}^{+}-113,4 \%\right), 199 \\
\left(\mathrm{M}^{+}-141,3 \%\right), 185\left(\mathrm{M}^{+}-155,\right. \\
13 \%), 171\left(\mathrm{M}^{+}-169,6 \%\right), 143 \\
\left(\mathrm{M}^{+}-197,3 \%\right), 129\left(\mathrm{M}^{+}-211,\right. \\
30 \%), 116\left(\mathrm{M}^{+}-224,10 \%\right), 97 \\
\left(\mathrm{M}^{+}-243,11 \%\right), 83\left(\mathrm{M}^{+}-257,\right. \\
15 \%), 73\left(\mathrm{M}^{+}-267,32 \%\right), 56 \\
\left(\mathrm{M}^{+}-284,100 \%\right), 43\left(\mathrm{M}^{+}-\right. \\
297,32 \%) .\end{array}$ \\
\hline
\end{tabular}


Table 5 GC-MS of Fraction F47 from Stokeyia indica

\begin{tabular}{|c|c|c|c|c|c|c|}
\hline $\begin{array}{l}\text { Scan } \\
\text { No. }\end{array}$ & Systematic Name & $\begin{array}{l}\text { Common } \\
\text { Name }\end{array}$ & $\begin{array}{l}\text { Molecular } \\
\text { Formula }\end{array}$ & $\begin{array}{l}\text { Mol. } \\
\text { Wt. }\end{array}$ & $\begin{array}{l}\text { Retention } \\
\text { Time }\end{array}$ & Mass \& Fragmentation Pattern \\
\hline 839 & Methyl-n-nonadecanoate & & $\mathrm{C}_{20} \mathrm{H}_{40} \mathrm{O}_{2}$ & 312 & 34.2 & $\begin{array}{l}\text { GC-MS m/Z: rel. Inten: } 312\left(\mathrm{M}^{+}, 3 \%\right), 269\left(\mathrm{M}^{+}-43,1 \%\right), 257 \\
\left(\mathrm{M}^{+}-55,41 \%\right), 239\left(\mathrm{M}^{+}-73,26 \%\right), 227\left(\mathrm{M}^{+}-85,1 \%\right), 213 \\
\left(\mathrm{M}^{+}-99,5 \%\right), 199\left(\mathrm{M}^{+}-113,1 \%\right), 185\left(\mathrm{M}^{+}-127,5 \%\right), 171 \\
\left(\mathrm{M}^{+}-141,4 \%\right), 157\left(\mathrm{M}^{+}-155,3 \%\right), 143\left(\mathrm{M}^{+}-169,2 \%\right), 129 \\
\left(\mathrm{M}^{+}-183,23 \%\right), 116\left(\mathrm{M}^{+}-196,8 \%\right), 97\left(\mathrm{M}^{+}-215,7 \%\right), 85 \\
\left(\mathrm{M}^{+}-227,9 \%\right), 73\left(\mathrm{M}^{+}-239,28 \%\right), 56\left(\mathrm{M}^{+}-256,100 \%\right), 43 \\
\left(\mathrm{M}^{+}-269,31 \%\right) .\end{array}$ \\
\hline 712 & Methyl-n-hexadecanoate & $\begin{array}{l}\text { Methyl } \\
\text { palmitate }\end{array}$ & $\mathrm{C}_{17} \mathrm{H}_{34} \mathrm{O}_{2}$ & 270 & 29.33 & $\begin{array}{l}\text { GC-MS m/z: rel. Inten: } 270\left(\mathrm{M}^{+}, 12 \%\right), 239\left(\mathrm{M}^{+}-31,9 \%\right), 227 \\
\left(\mathrm{M}^{+}-43,18 \%\right), 199\left(\mathrm{M}^{+}-71,6 \%\right), 171\left(\mathrm{M}^{+}-99,5 \%\right), 143 \\
\left(\mathrm{M}^{+}-127,23 \%\right), 129\left(\mathrm{M}^{+}-141,9 \%\right), 87\left(\mathrm{M}^{+}-183,68 \%\right), 74 \\
\left(\mathrm{M}^{+}-196,100 \%\right), 55\left(\mathrm{M}^{+}-215,17 \%\right), 43\left(\mathrm{M}^{+}-227,18 \%\right) .\end{array}$ \\
\hline 811 & Methyl octadecanoate & $\begin{array}{l}\text { Methyl } \\
\text { stearate }\end{array}$ & $\mathrm{C}_{19} \mathrm{H}_{38} \mathrm{O}_{2}$ & 298 & 33.13 & $\begin{array}{l}\text { GC-MS m/z: rel. Inten: } 298\left(\mathrm{M}^{+}, 9 \%\right), 267\left(\mathrm{M}^{+}-31,4 \%\right), 255 \\
\left(\mathrm{M}^{+}-43,12 \%\right), 241\left(\mathrm{M}^{+}-57,2 \%\right), 213\left(\mathrm{M}^{+}-85,1 \%\right), 199\left(\mathrm{M}^{+}\right. \\
-99,7 \%), 185\left(\mathrm{M}^{+}-113,3 \%\right), 157\left(\mathrm{M}^{+}-141,2 \%\right), 143\left(\mathrm{M}^{+}-\right. \\
\text {155, 18\%), } 129\left(\mathrm{M}^{+}-169,7 \%\right), 111\left(\mathrm{M}^{+}-187,3 \%\right), 101\left(\mathrm{M}^{+}-\right. \\
\text {197, 6\%), } 87\left(\mathrm{M}^{+}-211,77 \%\right), 74\left(\mathrm{M}^{+}-224,100 \%\right), 55\left(\mathrm{M}^{+}-\right. \\
\text {243, 15\%), } 43\left(\mathrm{M}^{+}-255,19 \%\right) .\end{array}$ \\
\hline 928 & Octadecanoic acid, butyl ester & & $\mathrm{C}_{22} \mathrm{H}_{44} \mathrm{O}_{2}$ & 340 & 37.62 & $\begin{array}{l}\text { GC-MS m/Z: rel. Inten: } 340\left(M^{+}, 5 \%\right), 297\left(M^{+}-43,1 \%\right), 285 \\
\left(M^{+}-55,42 \%\right), 267\left(M^{+}-73,24 \%\right), 255\left(M^{+}-85,2 \%\right), 241 \\
\left(M^{+}-99,9 \%\right), 227\left(M^{+}-113,2 \%\right), 213\left(M^{+}-127,0.5 \%\right), 199 \\
\left(M^{+}-141,2 \%\right), 185\left(M^{+}-155,10 \%\right), 171\left(M^{+}-169,3 \%\right), 157 \\
\left(M^{+}-183,1 \%\right), 143\left(M^{+}-197,3 \%\right), 129\left(M^{+}-211,26 \%\right), 116 \\
\left(M^{+}-224,10 \%\right), 97\left(M^{+}-243,8 \%\right), 83\left(M^{+}-257,12 \%\right), 73 \\
\left(M^{+}-267,28 \%\right), 56\left(M^{+}-284,100 \%\right), 43\left(M^{+}-297,30 \%\right) .\end{array}$ \\
\hline
\end{tabular}

cholesterol as compared to acetaminophen intoxicated rats. An interruption within cholesterol metabolism may possibly due to liver parenchymal cell deaths in due course directed toward the interruption of lipid metabolism in the liver [31]. Khan et al. [32] reported that as a result of the reduction of lipase activity, triglyceride levels increased which possibly directed to reduce triglyceride hydrolysis. It has also been observed that rats pre- 
treated with ethanol extract of $S$. indica reinstate the cholesterol concentration in acetaminophen intoxicated rats; these consequences are in conformity with the results of Bigoniya and Rana [33].

There are reports that hepatic lipid peroxidation elevated in acetaminophen toxicity $[34,35]$. In this study, acetaminophen intoxication also consequences in augmentation in lipid peroxidation, it is specified through the considerable augmentation in MDA. Extreme reactive oxygen specie (ROS) production activates the procedure of lipid peroxidation in cell membranes and results in obliteration of cells component and cells death. Whereas pretreatment of $S$. indica reinstate the hepatic GSH concentration and decreased the formation of MDA in acetaminophen-intoxicated rats which are in conformity by prior reports [36, 37]. The histopathology study of the liver also showed hepatoprotective effect of S.indica. The acetaminophen treated animals showed centrilobular necrosis with vacuolar cytoplasmic deterioration around the central vein, hepatic degeneration, destruction of lobular architecture and nuclear degeneration, while $S$. indica treated rats showed more or less normal hepatic architecture.

In this study, GC-MS analysis of two oily fractions of ethanol extract of S.indica eluted from column chromatography revealed the presence of several fatty acids including methyl palmitate which possessed antioxidant property. Fatty acid from a brown alga Spatoglossum asperum is known to possess various biological activity [38]. Hepato-protective potential of Sindica may be due to presence of methyl palmitate, that has been reported to ameliorate Aspartate Aminotransferase (ASAT), LDH (lactic dehydrogenase), serum glucose concentration in galactosamine intoxicated rats alongwith decresing the liver necrosis and inflammatory reactions [39]. Another report also supports this result that toxicity of carbon tetrachloride $\left(\mathrm{CCl}_{4}\right)$ to rats was decreased by methyl palmitate prior to intragastric $\mathrm{CCl}_{4}$ administration. Methyl palmitate decreases the $\mathrm{CCl}_{4}$-induced elevation in hepatic triglyceride content and in GPT (serum glutamic-pyruvic transaminase) activity and attenuate the $\mathrm{CCl}_{4}$ induced adverse effects on the liver tissue [40].

\section{Conclusion}

Results of our study indicate that seaweed, S.indica was effective in suppressing acetaminophen induced damage to liver. It was able to reduce all the elevated biochemical parameters and had therapeutic and preventive effect against acetaminophen induced hepatic and renal damage. The preventive activity of $S$. indica against oxidative stress may be due to the presence of fatty acids methyl palmitate, which is reported to possess antioxidant and hepatoprotective properties.

\section{Abbreviations}

ALP: Alkaline phosphatase; ALAT: Alanine transaminase; ASAT: Aspartate transaminase; $\mathrm{CCl}_{4}$ : Carbon tetrachloride; GC/MS: Gas chromatography/mass spectroscopy; GPT: Glutamic-pyruvic transaminase; He: Helium; LDH: Lactate dehydrogenase; MDA: Malondialdehyde; PUFA: Polyunsaturated fatty acids; TBARS: Thiobarbituric acid reactive substance

\section{Acknowledgements}

Authors are thankful to Dr. Aisha Begum, Department of Botany, University of Karachi for the identification of seaweed.

\section{Authors' contributions}

DT and AT carried out the collection of plant, extraction process and wrote the manuscript. DT carried out the animal study. Column chromatography and GC-MS analysis was done by AT. VUA helped in analyzing the GC/MS data. VS, JA and SEH helped in the seaweed collection, supervised research work and improve the quality of final version of manuscript. All authors read and approved the final manuscript.

\section{Funding}

Financial support provided by the Higher Education Commission, Pakistan (Grant \# NRPU-4505) is sincerely acknowledged.

\section{Availability of data and materials}

The datasets analyzed during the current study are available from the corresponding author on request.

Ethics approval and consent to participate

All experiments were carried out according to the guidelines for care and use of experimental animals and approved by the Institutional Animal Ethical Committee, University of Karachi.

\section{Consent for publication}

Not applicable.

\section{Competing interests}

The authors declare that they have no competing interests.

\section{Author details}

${ }^{1}$ Department of Biochemistry, University of Karachi, Karachi 75270, Pakistan. ${ }^{2}$ Department of Food Science \& Tech, University of Karachi, Karachi 75270, Pakistan. ${ }^{3} \mathrm{HEJ}$ Research Institute of Chemistry \& ICCBS, University of Karachi, Karachi, Pakistan. ${ }^{4}$ Department of Botany, University of Karachi, Karachi 75270, Pakistan.

Received: 3 October 2018 Accepted: 28 July 2019

Published online: 12 August 2019

References

1. Parmar SR, Patel HV, Kalia K. Hepatoprotective activity of some plants extracts against paracetamol-induced hepatotoxicity in rats. J Herb Med Toxicol. 2010;4:101-6.

2. Friedman SE, Grendell JH, Mc Quaid KR. Current diagnosis \& treatment in gastroenterology. New York: Lang Medical Books/McGraw-Hill; 2003. p. 664-79.

3. Aashish P, Tarun S, Pallavi B. Drug-induced hepatotoxicity. A review. J Appl Pharm Sci. 2012;2:233-43.

4. Hira K, Sultana V, Khatoon N, Ara J, Ehteshamul-Haque S. Protective effect of crude sulphated polysaccharides from Sargassum Swartzii (turn.) c.ag. Against acetaminophen induced liver toxicity in rats. Clin Phytosci. 2019; 5(14). https://doi.org/10.1186/s40816-019-0108-0.

5. Reuben A, Koch DG, Lee WM. Drug-induced acute liver failure: results of a US multicenter, prospective study. Hepatology. 2010;52:2065-76.

6. Lee CH, Park SW, Kim YS. Protective mechanism of glycyrrhizin on acute liver injury induced by carbon tetrachloride in mice. Biol Pharm Bull. 2007; 30:1898-904.

7. Hira K, Sultana V, Ara J, Ehteshamul-Haque S, Athar M. Hepatoprotective potential of three Sargassum species from Karachi coast against carbon tetrachloride and acetaminophen intoxication. J Coast Life Med. 2016:4:10-3.

8. Hira K, Sultana V, Ara J, Ehteshamul-Haque S. Protective role of Sargassum species in liver and kidney dysfunctions and associated disorders in rats intoxicated with carbon tetrachloride and acetaminophen. Pak J Pharm Sci. 2017;30:721-8.

9. Mayer AM, Rodriguez AD, Berlinck RG, Fusetani N. Marine compounds with antibacterial, anticoagulant, antifungal, anti-inflammatory, antimalarial, 
antiprotozoal, antituberculosis, and antiviral activities; affecting the immune and nervous system, and other miscellaneous mechanisms of action. Comp Biochem Physiol C Toxicol Pharmacol. 2011;153:191-222.

10. Tariq A, Ara J, Sultana V, Ehteshamul-Haque AM. Antioxidant potential of seaweeds occurring at Karachi coast of Pakistan. J Appl Bot Food Qual. 2011;84:207-12.

11. Tariq A, Athar M, Ara J, Sultana V, Ehteshamul-Haque S, Ahmad M. Biochemical evaluation of antioxidant activity in extracts and polysaccharide fractions of seaweeds. Glob J Environ Sci Manag. 2015;1(1):47-62.

12. Van Ginneken VJ, Helsper JP, deVisser W, Van Keulen H, Brandenburg WA. Polyunsaturated fatty acids in various macroalgal species from North Atlantic and tropical seas. Lipids Health Dis. 2011;10:104.

13. Huang CB, Ebersole JL. A novel bioactivity of omega-3 polyunsaturated fatty acids and their ester derivatives. Mol Oral Microbiol. 2010;25:75-80.

14. Guedes AC, Amaro HM, Malcata FX. Microalgae as sources of high addedvalue compound a brief review of recent work. Biotechnol Prog. 2011;2: 597-613.

15. Mozaffarian D, Wu JH. Omega-3 fatty acids and cardiovascular disease effects on risk factors, molecular pathways, and clinical events. J Am Coll Cardiol. 2011;58:2047-67.

16. Abbas A, Shameel M. Studies on the anatomy of a controversial brown alga, Cystoseira indica. Proc Pak Acad Sci. 2010;47:11-7.

17. Ara J, Sultana V, Ehteshamul-Haque S, Qasim R, Ahmad VU. Cytotoxic activity of marine macro-algae on Artemia salina (brine shrimp). Phytother Res. 1999;13:304-7.

18. Ayesha H, Sultana V, Ara J, Ehteshamul-Haque S. In vitro cytotoxicity of seaweed from Karachi coast on brine shrimp. Pak J Bot. 2010;42:3555-60.

19. Ruqqia K, Sultana V, Ara J, Ehteshamul-Haque S, Athar M. The hypolipidaemic potential of seaweeds in normal, triton-induced and highfat diet- induced hyperlipidemic rats. J Appl Phycol. 2015;27:571-9.

20. Akhtar P, Hira K, Ambreen, Sultana V, Ara J, Ehteshamul-Haque S. Hypoglycemic potential of some seaweeds from Karachi coast of Pakistan. Pak J Pharm Sci. 2019;32:1599-1605

21. Ohkawa H, Ohishi N, Yagi K. Assay for lipid peroxides in animal tissues by the thiobarbitoric acid reaction. Anal Biochem. 1979;95:351.

22. Samarth RM, Panwar M, Kumar M, Soni A, Kumar M, Kumar A. Evaluation of antioxidant and radical-scavenging activities of certain radioprotective plant extracts. Food Chem. 2008;106:868-73.

23. Compernolle F, Van Hees GP, Blanckaert N, Heirwegh KPM. Glucuronic acid conjugates of bilirubin-IXa in Normal bile compared with post-obstructive bile. Biochem J. 1978;171:185-201.

24. Bun SS, Bun H, Guedon D, Rosier C, Oliver E. Effect of green tea extracts on liver functions in Wistar rats. Food Chem Toxicol. 2006;44:1108-13.

25. Pushpavalli G, Veeramani C, Pugalendi KV. Influence of chrysin on hepatic marker enzymes and lipid profile against D-galactosamine-induced hepatotoxicity in rats. Food Chem Toxicol. 2010;48:1654-9.

26. Omidi A, Riahinia N, MontazerTorbati MB, Behdani MA. Hepatoprotective effect of Crocus sativus (saffron) petals extracts against acetaminophen toxicity in male Wistar rats. Avicenna J Phytomed. 2014:4:330-6.

27. El Morsy EM, Kamel R. Protective effect of artichoke leaf extract against paracetamol-induced hepatotoxicity in rats. Pharm Biol. 2015;53:167-73.

28. Srinivasan V, Panneerselvam R, Gunasekaran S, Palani S. Ethanolic extract of Melia azadirachta against acetaminophen induced nephrotoxicity. Int J Pharm Tech Res. 2014;6(1):70-9.

29. Yousef Ml, Omar SA, El-Guendi MI, Abdelmegid LA. Potential protective effects of quercetin and curcumin on paracetamol-induced histological changes, oxidative stress, impaired liver and kidney functions and hemtotoxicity in the rat. Food Chem Toxicol. 2010;48(11):3246-61.

30. Mikolasevic I, Žutelija M, Mavrinac V, Orlic L. Dyslipidemia in patients with chronic kidney disease: etiology and management. Int J Nephrol Renovasc Dis. 2017;10:35-45.

31. Havel RJ. Functional activities of hepatic lipoproteins receptors. Annu Rev Physiol. 1986:48:119-34.

32. Khan V, Najmi AK, Akhtar M, Aqil M, Mujeeb M, Pillai KK. A pharmacological appraisal of medicinal plants with antidiabetic potential. J Pharm Bioallied Sci. 2012:4:27-42.

33. Bigoniya P, Rana AC. Protective effect of Wrightia tinctoria bark triterpenoidal fraction on CCl4-induced acute rat liver toxicity. Iran J Pharmacol Therapeut. 2010;9:55-62.

34. Dadkhah A, Fatemi F, Kazemnejad S, Rasmi Y, Ashrafi-Helen J, Allameh A Differential effects of acetaminophen on enzymatic and non-enzymatic antioxidant factors and plasma total antioxidant capacity in developing and adult rats. Mol Cell Biochem. 2006;281:145-52.

35. Dadkhah A, Fatemi F, Alipour M, Ghaderi Z, Zolfaghari F, Razdan F. Protective effects of Iranian Achillea wilhelmsii essential oil on acetaminophen-induced oxidative stress in rat liver. Pharm Biol. 2015;53:220-7.

36. Luvone T, De Filippis D, Esposito G, DAmico A, Izzo AA. The spice sage and its active ingredient rosmarinic acid protect PC12 cells from amyloid-beta peptide-induced neurotoxicity. J Pharmacol Exp Ther. 2006;317:1143-9.

37. Ramalho LN, Pasta AA, Terra VA, Augusto M, Sanches SC, Souza-Neto FP, Cecchini R, Gulin F, Ramalho FS. Rosmarinic acid attenuates hepatic ischemia and reperfusion injury in rats. Food Chem Toxicol. 2014;74:270-8.

38. Ara J, Sultana V, Qasim R, Ehteshamul-Haque S, Ahmad VU. Biological activity of Spatoglossum asperum: a brown alga. Phytother Res. 2005;19:618-23.

39. Al Tuwaijri A, Akdamar K, Diluzio R. Modification of galactosamine induced liver injury in rats by reticuloendothelial stimulation or depression. Hepatology. 1981;1(2):107-13.

40. Rodríguez-Rivera A, Galicia-Moreno M, Reyes-Gordillo K, Segovia J, Vergara P, Moreno MG, Shibayama M, Tsutsumi V, Muriel P. Methyl palmitate prevents CCl4-induced liver fibrosis. J Appl Toxicol. 2008;28:1021-6.

\section{Publisher's Note}

Springer Nature remains neutral with regard to jurisdictional claims in published maps and institutional affiliations.

\section{Submit your manuscript to a SpringerOpen ${ }^{\circ}$ journal and benefit from:}

- Convenient online submission

Rigorous peer review

- Open access: articles freely available online

High visibility within the field

- Retaining the copyright to your article

Submit your next manuscript at $>$ springeropen.com 